\title{
AN INTEGRATED FOOTPRINT BASED APPROACH FOR ENVIRONMENTAL LABELLING OF PRODUCTS: THE CASE OF DRINKING BOTTLED WATER
}

\author{
V. NICCOLUCCI ${ }^{1}$, B. RUGANI ${ }^{1}$, S. BOTTO ${ }^{2} \&$ C. GAGGI ${ }^{2}$ \\ ${ }^{1}$ Department of Chemistry, University of Siena, Italy. \\ ${ }^{2}$ Department of Environmental Sciences "G. Sarfatti", University of Siena, Italy.
}

\begin{abstract}
The aim of this paper is to present an integrated approach to be used in environmental labelling of products. The approach is based on the joint use of three methods inspired by similar philosophy that capture different and complementary aspects of environmental issues. We call it CEW approach as it is based on the footprint family indicators: carbon footprint, ecological footprint and water footprint. Its pros and cons are discussed and an example of application to a product is included to illustrate its potential. A natural mineral water marketed in a 1.5 L PET bottle was chosen as case study and analyzed over its life cycle 'from cradle to gate', from the spring to the gate of the plant.

Keywords: bottled drinking water, carbon footprint, ecological footprint, environmental labelling, water footprint.
\end{abstract}

\section{INTRODUCTION}

Water is a resource on which our existence depends, but since it is provided to consumers by private or public companies, it is also an economic good with a production and distribution chain. Like any other good, supplying water to consumers has a cost in terms of environmental impact and depletion of resources. Control of this cost calls for a detailed monitoring of each step of the production chain or life cycle.

Consumers can also play a major role, preferring goods that are less resource intensive and have lower environmental impact [1]. To make informed choices, consumers require access to clear, relevant and reliable information about production [2]. This information should be in a usable form, at the retail outlet. This is the purpose of an ecological label. Ecological labels are documented recognition that activities, products or services comply with certain environmental standards. The most authoritative examples of eco-labels in Europe are Eco-labels [3] and Environmental Product Declarations (EPDs) [4]. The latter are currently being developed as a way of communicating environmentally relevant information in a comprehensible, yet value-neutral manner [5]. They are based on 'life cycle assessment' and provide a measure of environmental performance of the product (or service) over its entire production chain [6].

Growing environmental consciousness of customers, due also to improving access to reliable information, makes it possible to develop a new kind of label that enables consumers to choose between goods that are equal in satisfying their needs, but with different environmental impact, like the Eco-label. The new label should contain more relevant and reliable information than the Ecolabel, which is merely a binary form of labeling (i.e. 'this product was/was not produced in accordance with an environmental standard'). EPD contains this information, but is a document, rather than a label, and is therefore unsuitable for consumer choices.

The aim of this study was to provide a new scheme for environmental labelling of products, based on an integrated footprint approach that involves three different methods belonging to the footprint family: carbon, ecological and water footprint. The common aim of all these methods is to account for the human appropriation of natural resources even if with different ways and complementary perspectives: respectively the effect of resource use on climate change, the ecologically productive 
area exploited to make available the resources and total direct and indirect volume of water needed in each step within the supply chain of a generic product.

\section{METHODOLOGY}

The footprint approach (hereafter CEW approach) joins three different footprint-based indicators: the carbon footprint (CF), ecological footprint (EF) and water footprint (WF). Each of them is based on a life cycle approach that accounts for all the resources required from cradle to gate to obtain a product or sustain an activity. Then each indicator is able to provide information on the environmental performances of a product or service by using a different metrics: namely energy use in terms of the total volume of carbon dioxide $\left(\mathrm{CO}_{2}\right)$ emitted $(\mathrm{CF})$, the use of bio-productive space $(\mathrm{EF})$ and the total water consumption (WF). Their combination may be useful to characterize three significant environmental aspects of a production system in a single profile.

The main features of each footprint method are briefly presented below. The single profile combining the three footprint outcomes is provided as a preliminary basis for a new environmental label for products or services.

\subsection{Carbon footprint}

The term carbon footprint refers to the overall amount of greenhouse gas (hereafter GhG) emissions of a product, good or service, over its supply-chain from raw materials to disposal/recycling [7]. CF includes the main greenhouse gases carbon dioxide $\left(\mathrm{CO}_{2}\right)$, methane $\left(\mathrm{CH}_{4}\right)$ and nitrous oxide $\left(\mathrm{N}_{2} \mathrm{O}\right)$, together with families of gases including hydrofluorocarbons (HFCs) and perfluorocarbons (PFCs). It is quantified by indicators such as global warming potential (GWP), which relates the radiative forcing impact and the lifetime in atmosphere of one unit mass of a given $\mathrm{GhG}$ to an equivalent unit of $\mathrm{CO}_{2}$ over a given period of time, such as 100 years $\left(\mathrm{GWP}_{100}\right)$, as defined by the Intergovernmental Panel on Climate Change [8]. Since the GWP of $\mathrm{CO}_{2}$ is 1 , the GWP of other gases is expressed in relation to the GWP of $\mathrm{CO}_{2}$ from fossil carbon sources. Thus, GWPs of different emissions can be added together to obtain a single indicator that expresses the overall contribution to climate change.

Hence, a carbon footprint is a life cycle assessment limited to emissions affecting climate change. Suitable background data sources for CF are therefore those in existing life cycle analysis (LCA) databases.

The $\mathrm{CF}$ of a generic product can be calculated as follows:

$$
\mathrm{CF}_{\text {product }}=\sum_{i=1}^{n} \sum_{j=1}^{n} \mathrm{GWP}_{i} \times Q_{i, j},
$$

where GWP is the global warming potential of each greenhouse gas $i$ considered and $Q$ is the quantity of each greenhouse gas $i$ emitted during the production of each input $j$ involved in the life cycle of the product.

$\mathrm{CF}$ is expressed as mass of $\mathrm{CO}_{2}$ equivalent $\left(\mathrm{kg} \mathrm{CO}_{2}\right.$-eq.), making the global warming effects of different greenhouse gases comparable and additive and providing a powerful informative tool. It enables companies to collect the information they need to: (i) reduce GhG emissions; (ii) identify cost saving opportunities; (iii) demonstrate environmental/corporate responsibility; and (iv) meet customer demands for information on product CFs [9].

\subsection{Ecological footprint}

The ecological footprint is a biophysical resource accounting method that provides a measure of the load imposed on the ecosphere by a population or a production activity in terms of total area occupied [10]. By definition the EF is the sum of the areas of land and sea necessary to produce the resource 
and absorb the waste produced [10-12]. Its units are global hectares (gha), or hectares with global average productivity [13]. It is a normalized unit useful for comparing lands with different productivities [14]. Six categories of productive land are usually included in the EF calculation: cropland, grazing land, fishing grounds, forest area, built-up area and energy land or carbon sequestration land (the amount of forest area required to capture $\mathrm{CO}_{2}$ emissions not sequestered by oceans) [10]. Yield factor and equivalence factor are used to translate these six land types into global hectares. Equivalence factor adjusts for the relative productivity of the six categories of land and water, while yield factor adjusts for local to global average productivity of the same land categories [13, 14].

The EF of a product is defined as the sum of the footprints of all of the activities required to create, use and/or dispose of that product during its life cycle [15].

$$
\mathrm{EF}_{\text {product }}=\sum_{i=1}^{6} \sum_{j=1}^{n} \mathrm{EQF}_{i} \times \mathrm{EF}_{i, j} \text {, }
$$

where $i$ refers to the six different types of land (cropland, grazing land, fishing grounds, forest area, built-up land and energy land); $j$ refers to the $n$-inputs needed for the production phases; $\mathrm{EQF}_{i}$ is the equivalence factor of the $i$ th land. The EF of a generic input $j$ is the sum of all the land necessary to produce that input. For example: to produce 1 tonne of maize, cropland land and energy land are necessary to cultivate and harvest the crop, and to transport 1 tonne of maize energy land (to sequester all the $\mathrm{CO}_{2}$ emissions released by the consumption of fossil fuels) and built up land (for maintenance, roads, etc.) are necessary.

The EF of a product is expressed in global hectare years (gha yr) or global metre years $\left(\mathrm{gm}^{2} \mathrm{yr}\right)$.

\subsection{Water footprint}

The water footprint is a new method of calculating total water demand by activities and products [16] based on the virtual water concept proposed by Allan in 1998 [17]. The virtual water content (VWC) of a product or a commodity is defined as the volume of fresh water needed to produce the product, measured where the product was produced (production-site definition) $[18,19]$. The WF is measured in liters or $\mathrm{m}^{3}$ of water and includes direct (contained in) and indirect (not contained in) water use.

The WF of the production process of a generic product $\mathrm{p}$ can be calculated according to the chain-summation approach [18]:

$$
\mathrm{WF}_{\text {prod }}[p]=\frac{\sum_{s=1}^{k} \mathrm{WF}_{\text {proc }}[s]}{P[p]},
$$

where the $\mathrm{WF}_{\text {proc }}[s]$ is the process water footprint of process step s and $P[p]$ the quantity of product $p$.

The total WF accounts for both real and virtual components as in eqn 4:

$$
\mathrm{WF}_{\text {product }}=\mathrm{WF}_{\mathrm{v}}+\mathrm{WF}_{\mathrm{r}} \text {, }
$$

where $\mathrm{WF}_{\mathrm{v}}$ is the virtual water content (total water consumption necessary to provide each life cycle inventory input) and $\mathrm{WF}_{\mathrm{r}}$ is the real water physically contained in the product (when countable).

\section{CASE STUDY}

We analyzed a brand of Italian natural mineral bottled water produced by a company (BAM Cerelia S.r.1.) committed to environmental management practices as shown by EMAS registration and ISO 14001 certification. From the Italian bottled water market point of view, this company is 
small, bottling about $8 \mathrm{ML}$ per year, which is sold in a small local area. The most recently updated version of the EPD [20] provided all the information and data required for the footprint analyses. Unless otherwise specified, the data is that of the year 2007.

Life cycle analysis was only 'from cradle to gate', i.e. from the springs to the bottled water ready for distribution. The main steps considered were: water withdrawal, bottle unwrapping, ozone production for bottle flushing, bottle flushing, filling, corking, labeling, packaging, wrapping and stocking. Distribution, consumption and end-of-life phases were not included in the system boundaries. The functional unit (F.U.) was $1.5 \mathrm{~L}$ of natural mineral water in a PET bottle.

The same life cycle inventory (LCI) was used to calculate the three footprints, using LCA procedures and system boundaries as defined in the product category rules (PCR) of Cerelia natural mineral water [21]; i.e. from cradle to gate (from extraction of raw materials up to the distribution of the product to consumers). To calculate the three footprints, the same background data was used, which referred to upstream input-output processes (background data) of each input provided by Cerelia's EPD [20]. These processes were found in specific databases and literature.

\section{RESULTS}

In this section an overview of the potential of the CEW is illustrated by analyzing a natural mineral water produced in Italy and marketed in PET bottles. Table 1 shows the life cycle inventory (first column) from

Table 1: Life cycle inventory and EF, CF and WF results for Cerelia natural mineral water bottled in PET container.

\begin{tabular}{|c|c|c|c|c|}
\hline CERELIA - EPD 2007 & $\begin{array}{l}\text { Inventory of } \\
\text { inputs }\left(\mathrm{kg}^{*}\right)\end{array}$ & $\begin{array}{c}\mathrm{EF} \\
\left(\mathrm{gm}^{2} \mathrm{yr}\right)\end{array}$ & $\begin{array}{c}\mathrm{CF} \\
\text { (kg CO}{ }_{2} \text {-eq.) }\end{array}$ & $\begin{array}{l}\text { WF } \\
(\mathrm{L})\end{array}$ \\
\hline \multicolumn{5}{|l|}{ Primary packaging } \\
\hline Bottle (PET) & $3.70 \mathrm{E}-02$ & $4.21 \mathrm{E}-01$ & $1.73 \mathrm{E}-01$ & $1.89 \mathrm{E}-01$ \\
\hline Cap (PP) & $2.50 \mathrm{E}-03$ & $1.18 \mathrm{E}-03$ & $4.91 \mathrm{E}-03$ & $1.20 \mathrm{E}-02$ \\
\hline Label (paper) & $2.02 \mathrm{E}-03$ & $5.17 \mathrm{E}-03$ & $3.18 \mathrm{E}-03$ & $6.58 \mathrm{E}-02$ \\
\hline Glue & $3.00 \mathrm{E}-04$ & $3.72 \mathrm{E}-04$ & $1.24 \mathrm{E}-04$ & $2.78 \mathrm{E}-04$ \\
\hline Sub-total & & $4.38 \mathrm{E}-01$ & $1.82 \mathrm{E}-01$ & $2.67 \mathrm{E}-01$ \\
\hline \multicolumn{5}{|l|}{ Secondary packaging } \\
\hline Film (LDPE) & $4.00 \mathrm{E}-03$ & $1.78 \mathrm{E}-02$ & $8.32 \mathrm{E}-03$ & $1.36 \mathrm{E}-02$ \\
\hline Handle (LDPE) & $1.70 \mathrm{E}-04$ & $7.55 \mathrm{E}-04$ & $3.54 \mathrm{E}-04$ & $5.78 \mathrm{E}-04$ \\
\hline Sub-total & & $1.85 \mathrm{E}-02$ & $8.68 \mathrm{E}-03$ & $1.42 \mathrm{E}-02$ \\
\hline \multicolumn{5}{|l|}{ Tertiary packaging } \\
\hline Cardboard & $2.10 \mathrm{E}-03$ & $5.38 \mathrm{E}-03$ & $1.04 \mathrm{E}-03$ & $6.84 \mathrm{E}-02$ \\
\hline Pallet (wood) & $5.90 \mathrm{E}-04$ & $5.99 \mathrm{E}-07$ & $1.19 \mathrm{E}-03$ & $1.29 \mathrm{E}-03$ \\
\hline Sub-total & & $5.38 \mathrm{E}-03$ & $2.23 \mathrm{E}-03$ & $6.97 \mathrm{E}-02$ \\
\hline \multicolumn{5}{|l|}{ Other materials } \\
\hline Lubricating oil & $2.80 \mathrm{E}-06$ & $2.38 \mathrm{E}-08$ & $8.20 \mathrm{E}-07$ & $6.72 \mathrm{E}-06$ \\
\hline \multicolumn{5}{|l|}{ Water } \\
\hline Water of system processing (L) & $6.33 \mathrm{E}+00$ & $6.50 \mathrm{E}-03$ & $1.35 \mathrm{E}-03$ & $6.33 \mathrm{E}+00$ \\
\hline \multicolumn{5}{|l|}{ Energy } \\
\hline Electricity $(\mathrm{kWh})$ & $2.86 \mathrm{E}-02$ & $3.81 \mathrm{E}-02$ & $2.03 \mathrm{E}-02$ & $3.04 \mathrm{E}-01$ \\
\hline \multicolumn{5}{|l|}{ Product } \\
\hline Natural mineral water & $1.50 \mathrm{E}+00$ & & & \\
\hline Total footprints & & $5.06 \mathrm{E}-01$ & $2.14 \mathrm{E}-01$ & $6.98 \mathrm{E}+00$ \\
\hline
\end{tabular}

*If not specifically expressed. 
the EPD of Cerelia [20], together with the relative EF (second column), CF (third column) and WF (fourth column). Calculation of the three indicators was enabled by specific conversion factors available in the literature, specific databases or directly from the industrial reports. The main data included packaging (primary, secondary and tertiary), other materials (e.g. lubricating oil), water and electricity.

The EF results indicate that the total bioproductive area required was $0.51 \mathrm{gm}^{2} \mathrm{yr}$ per F.U., most of which is energy land and forest area needed to absorb the $\mathrm{CO}_{2}$ emissions. This value agrees with others found in the literature [12].

The CF, which we calculated again, although Cerelia's EPD already provides it, indicated a production of about $0.21 \mathrm{~kg} \mathrm{CO}_{2}$-eq per F.U.; this value is about $60 \%$ higher than the result presented in Cerelia's EPD, namely $0.13 \mathrm{~kg} \mathrm{CO}_{2}$-eq. Although the same input data was used, the gap may be due to the use of different background data, as specified in section 3 .

When these values are displayed on the label it is easy to compare products produced in different ways, for example different kinds of container (PET, glass or organic materials), weights of container, use of resources (renewable or otherwise) and so on. This information is very important to responsible consumers wishing to reduce their impact on the planet.

The EF and CF both highlight the importance of primary packaging (i.e. the PET bottle and the PP cap). Plastic materials are particularly energy intensive and responsible for a huge quantity of $\mathrm{CO}_{2}$ emissions. It is estimated that about $4 \mathrm{~kg} \mathrm{CO}_{2}$ are produced per $\mathrm{kg}$ of PET [22].

Obviously the EF and CF are concentrated more on the container than on the product, because spring water has neither ecological nor carbon footprint. On the contrary, water of system processing may have footprints, although very low, due to energy and materials required to make water available. The WF also counts the primary resource, i.e. water. In this case, the water dispersed for every $1.5 \mathrm{~L}$ is counted, due for example to change bottle size, different kinds of loss, the type of bottling (i.e. if continuous or discontinuous processes). The WF also considers the volume of water necessary to provide each inventoried input.

The WF results show that for every $1.5 \mathrm{~L}$ bottle of mineral water there is $5.50 \mathrm{~L}$ of ghost (or virtual). A future step will be to consider whether the process is open or closed, in other words, whether water is re-used in the plant or totally dispersed, especially in plastics production.

\section{DISCUSSION}

The CEW approach proposed in this study is based on the combined use of three indicators reflecting complementary aspects of the environmental impact of a specific product. No single indicator alone is completely exhaustive. The EF is considered the most complete indicator of the three but has some important limitations. According to the last guidelines of the National Footprint Accounts, traditional $\mathrm{EF}$ accounts only include $\mathrm{CO}_{2}$ emissions, while other greenhouse gases (methane, nitrous oxide, etc.) are not considered to have an additional footprint beyond the energy required for their production [14]. There are cases in which this last contribution is quite high (e.g. transport) and cannot be ignored. So we included the $\mathrm{CF}$ to count the total $\mathrm{CO}_{2}$ equivalent contribution based on global warming potentials, as suggested by some authors [23-25]. In this way a more complete greenhouse gases contribution is assessed.

Water is an enabler of bioproductivity (i.e. photosynthesis) not generally a product of ecosystems [14]. Thus the $\mathrm{EF}$ of a given quantity of water cannot be calculated with yield values in the same manner as a quantity of crop or wood product. Since water is becoming a strategic resource it is increasingly important to count it. The WF is the best indicator to quantify this environmental aspect.

The CEW approach showed some undoubted advantages. From the methodological point of view, the indicators it combines can be calculated from existing environmental assessments, such as EPDs. This enabled rapid and exhaustive calculation, since EPD is a detailed assessment of the main 
environmental impacts associated with the production of goods. In this way, EPDs of other goods can easily and unexpensively include the CEW information. The CEW is also easy to understand, being based on $\mathrm{L}$ of water, ha of space and $\mathrm{kg}$ of $\mathrm{CO}_{2}$.

From the consumer's point of view, the CEW suggests that a product has impacts on different environmental aspects. Labels such as the Eco-label only give binary information: consumers can only know whether or not the good was produced according to certain environmental standards. Among substitute goods, consumers can only see which have and which lack the Eco-label. The CEW provides more information, i.e. numerical values of the environmental performance with which to compare substitute products. What this performance means is also well specified. It means that the product contributes so much to global warming, requires so much ecologically productive land and consumes so much water, three different strategic aspects that can guide consumers' choices.

Application of the CEW label can also educate consumers on environmental issues, as it combines three advanced indicators. The case of drinking water shows that today's consumers are receptive enough to accept education of this kind. The Italian bottled water market offers more than 200 brands. According to Drichoutis et al. [26], a growing number of consumers read and compare labels before purchasing bottled water. They want to know the chemical composition of each one, because they are aware of the physiological consequences of different compositions. This practice should not be overlooked when discussing the basis of the CEW label. Consumers are used to comparing and choosing brands of water on the basis of numerical values. The numerical and detailed nature of the CEW seems to be a consumer-friendly tool.

On the other hand the CEW has some limitations. First of all, it should consider larger system boundaries, accounting for the entire life cycle, from cradle to grave and not just to the gate. At least two main phases should be included. The distribution from the gate to the market or directly to the table is an important point to highlight for consumers. Products with low 'food or product miles' should be encouraged. The end of life phase is another key point, especially for products sold in a container, as in this case. On the label, a proposal for the best end-of-life scenario might be added, making the CEW more reliable.

There may also be cases in which the CF and EF provide overlapping information; this is particularly true for industrial products where energy input is generally predominant.

Although the CEW combines three important environmental indicators, it does not provide an exhaustive environmental profile of the product. When an EPD with other kinds of environmental evaluation and certification of a product is not available, a limitation for calculating the CEW may be the quality of inputs and outputs of the life cycle inventory. Another limitation regards the specificity of conversion factors. This is especially true for the EF and WF methods. Finally the CEW combines three values that need to be considered separately, as they cannot be added together. Future research is needed to normalize the three indicators, providing a single tool based on the footprint performance of goods and services.

\section{CONCLUSION}

Lowering the environmental impact and consumption of resources associated with the production of goods is a matter of technologies and production monitoring. Studies on life cycles of goods can be used to obtain information and intervene at each step of the supply chain of a product. Consumers can also play a major role in environmental conservation, through the weight of their choices. Since consumption patterns can only be reshaped if consumers are well informed, ecological labels should be developed and promoted.

The CEW presented here combines three footprint indicators, each regarding a different strategic environmental aspect. They were applied to the case of bottled drinking water, using data contained 
in an existing EPD. This enabled rapid and exhaustive calculation and was undoubtedly a big advantage. The CEW approach is also a tool by which detailed assessments, such as EPDs, can be brought to consumer level.

A label based on the CEW informs consumers about important environmental aspects, providing numerical values, which can be used to compare different brands of the same good. In the case of bottled drinking water, consumers are already considering numerical values of chemical composition to make their choices; thus drinking water proves to be a good starting point for testing the CEW.

This indicator is not intended to inform consumers on whether or not a product is environmentally friendly, but is a fuller way of informing consumers about the environmental consequences of their choices.

\section{ACKNOWLEDGEMENTS}

Our sincere thanks to Nicoletta Patrizi for her precious work, and to two anonymous referees for their useful comments.

\section{REFERENCES}

[1] Mamouni Limnios, E.A., Ghadouani, A., Schilizzi, S.G.M. \& Mazzarol, T., Giving the consumer the choice: a methodology for product ecological footprint calculation. Ecological Economics, 68, pp. 2525-2534, 2009. doi:10.1016/j.ecolecon.2009.04.020

[2] Schmidt, H.J., Carbon footprinting, labeling and life cycle assessment. The International Journal of Life Cycle Assessment, 14, Supplement 1, S6-S9, 2009 doi:10.1007/s11367-009-0071-y

[3] Regulation (EC) No. 1980/2000 of the European Parliament and of the Council of 17 July 2000 on a revised community eco-label award scheme. Available on-line at: http://eur-lex.europa.eu/ LexUriServ/LexUriServ.do?uri=OJ:L:2000:237:0001:0012:en:PDF.

[4] ISO 14025:2006 Environmental labels and declarations - Type III environmental declarations - Principles and procedures, 2006.

[5] Swedish Environmental Management Council (MSR), Requirements for Environmental Product Declarations, EPD (MSR 1999:2). Available on-line at: www.environdec.com.

[6] Baldo, G.L., Marino, M. \& Rossi, S., Analisi del ciclo di vita LCA (Life Cycle Assessment). Gli strumenti per la progettazione sostenibile di materiali, prodotti e processi: Edizioni Ambiente, Italy, 2008.

[7] Wiedmann, T. \& Minx, J., A Definition of 'Carbon Footprint' (Chapter 1). Ecological Economics Research Trends, Nova Science Publishers, Hauppauge, New York, pp. 1-11, 2008.

[8] Intergovernmental Panel on Climate Change (IPCC), Climate Change 2007 - The Physical Science Basis. Contribution of Working Group I to the Fourth Assessment Report of the IPCC, 2007.

[9] Carbon Trust, Department for Environment, Food and Rural Affairs (DEFRA) \& British Standards (BSI), Guide to PAS 2050: How to assess the carbon footprint of goods and services. Great Britain, 2008.

[10] Wackernagel, M. \& Rees, W.E., Our Ecological Footprint: Reducing Human Impact on the Earth. New Society: Gabriola Island, British Columbia, 1996.

[11] Wackernagel, M. \& Kitzes, J., Ecological footprint, Encyclopedia of Ecology, Elsevier: Amsterdam, pp. 1031-1037, 2008. doi:10.1016/B978-008045405-4.00620-0

[12] Kitzes, J., Galli, A., Bagliani, M., Barrett, J., Dige, G., Ede, S., Erb, K-H., Giljum, S., Haberl, H., Hails, C., Jungwirth, S., Lenzen, M., Lewis, K., Loh, J., Marchettini, N., Messinger, H., Milne, K., Moles, R., Monfreda, C., Moran, D., Nakano, K., Pyhälä, A., Rees, W., Simmons, C., Wackernagel, M., Wada, Y., Walsh, C. \& Wiedmann, T., 
A research agenda for improving national ecological footprint accounts. Ecological Economics, 68(7), pp. 1991-2007, 2009.

[13] Galli, A., Kitzes, J., Wermer, P., Wackernagel, M., Niccolucci, V. \& Tiezzi, E., An exploration of the mathematics behind the ecological footprint. International Journal of Ecodynamics, 2(4), pp. 250-257, 2007. doi:10.2495/ECO-V2-N4-250-257

[14] Monfreda, C., Wackernagel, M. \& Deumling, D., Establishing national natural capital accounts based on detailed ecological footprint and biological capacity assessments. Land Use Policy, 21, pp. 231-246, 2004. doi:10.1016/j.landusepol.2003.10.009

[15] Global Footprint Network (GFN), Ecological footprint standards. Available on-line at:_ttp:// www.footprintnetwork.org/gfn_sub.php?content=standards, 2007.

[16] Hoekstra, A.Y. \& Hung, P.Q., Virtual water trade: a quantification of virtual water flows between nations in relation to international crop trade. Value of Water Research Report Series, vol.11. UNESCO-IHE, Delft, The Netherlands, 2002.

[17] Allan, J.A., Virtual water: a strategic resource, global solutions to regional deficits. Groundwater, 36(4), pp. 545-546, 1998. doi:10.1111/j.1745-6584.1998.tb02825.x

[18] Hoekstra, A.Y \& Chapagain, A.K., Globalization of water. Sharing the Planet's Freshwater Resources. Blackwell Publishing, Oxford: UK, pp. 207, 2008.

[19] Hoekstra, A.Y., Human appropriation of natural capital: a comparison of ecological footprint and water footprint analysis. Ecological Economics, 68(7), pp. 1963-1974, 2009. doi:10.1016/j. ecolecon.2008.06.021

[20] Cerelia Environmental Product Declaration. Cerelia natural mineral water packaged in $1.5 \mathrm{~L}$ PET bottle and $1 \mathrm{~L}$ glass bottle. Registration No. S-P-00123. Available on-line at: www.cerelia. it or www.environdec.com, 2007.

[21] The Swedish Environmental Management Council (MSR), Ciba Expert Services, Cerelia S.p.A., Product Category Rules (PCR) for preparing an environmental product declaration (EPD) for Natural Mineral Water. Registration No. 2006:07, Version 1.0. Available on-line at: www.environdec.com, 2007.

[22] Boustead, I., Eco-profiles of the European Plastics Industry. Reports for Plastics Europe. Available on-line at: http://lca.plasticseurope.org/index.htm, 2005.

[23] Lenzen, M. \& Murray, S.A., A modified ecological footprint method and its application to Australia. Ecological Economics, 37, pp. 229-255, 2001. doi:10.1016/S0921-8009(00)00275-5

[24] Barrett, J., Vallack, H., Jones, A. \& Haq, G., A material flow analysis and ecological footprint of York. Technical report. Stockholm Environment Institute, Stockholm, 2002

[25] Holden, E. \& Høyer, K.G., The ecological footprint of fuels. Transportation Research Part D: Transport and Environment, 10(5), pp. 395-403, 2005. doi:10.1016/j.trd.2005.04.013

[26] Drichoutis, A.C., Lazaridis, P., Nayga, N.M. Jr., On consumers' valuation of nutrition information. Bulletin of Economic Research, 61(3), pp. 223-247, 2009 doi:10.1111/j.14678586.2009.00303.x 